\title{
Perceived and actual risks of drought: household and expert views from the lower Teesta River Basin of northern Bangladesh
}

\author{
Roquia Salam ${ }^{1}$ - Bonosri Ghose ${ }^{1}$ Badhon Kumar Shill ${ }^{1} \cdot$ Md. Aminul Islam ${ }^{1}$. \\ Abu Reza Md. Towfiqul Islam ${ }^{1}$ (D) - Md. Abdus Sattar ${ }^{2}$. G. M. Monirul Alam³ . \\ Bayes Ahmed ${ }^{4}$
}

Received: 8 March 2021 / Accepted: 8 May 2021

(c) The Author(s) 2021

\begin{abstract}
Disaster risk perception and risk appraisal are essential in formulating an appropriate disaster risk reduction policy. This study examines the actual $v$ s perceived drought risks by constructing risk indices at the household and expert levels using survey data from the lower Teesta River Basin in northern Bangladesh. The survey data were collected from 450 farmers using a structured questionnaire conducted between August and September 2019. A composite drought risk index was developed to understand households' perceived and actual risks in the designated areas. The results show that the actual and perceived risk values differ significantly among the three case study sites locally known as Ganai, Ismail, and Par Sekh Sundar. The risk levels also differ significantly across the households' gender, income, occupation, and educational attainment. People with insolvent socioeconomic status are more prone to drought risk compared to others. Results also reveal that the mean level of perceived risk agrees well with the actual risk, whereas females perceive comparatively higher risk than their male counterparts. Expert views on drought risk are similar to the individual household level perceived risk. The outcomes of this study would assist the policymakers and disaster managers to understand the concrete risk scenarios and take timely disaster risk reduction actions for ensuring a drought-resistant society.
\end{abstract}

Keywords Drought risk perception · Actual risk and perceived risk · Disaster risk reduction $\cdot$ Teesta River $\cdot$ Bangladesh

Bayes Ahmed

bayes.ahmed@ucl.ac.uk

1 Department of Disaster Management, Begum Rokeya University, Rangpur 5400, Bangladesh

2 Department of Disaster Risk Management, Patuakhali Science and Technology University, Dumki, Patuakhali 8602, Bangladesh

3 Department of Agribusiness, Bangabandhu Sheikh Mujibur Rahman Agricultural University, Dhaka 1706, Bangladesh

4 Institute for Risk and Disaster Reduction (IRDR), University College London (UCL), Gower Street, London WC1E 6BT, UK 


\section{Introduction}

Risk perception as well as people's risk appraisal is the pivotal element for devising and applying disaster risk reduction strategies and plans (Sattar and Cheung 2019). There is a wide gap between people's risk perception and experts' risk appraisal (Garvin 2001). Ultimately, this gap creates difficulty in implementing disaster risk reduction plans or associated policies. Thus, it is essential to study people's risk perception and to investigate the disaster risk reduction (DRR) plans from both household's and experts' points of view.

According to the Global Climate Risk (GCR) index, Bangladesh is now ranked fifth extreme disaster risk-prone country in the world (Dastagir 2015). Among the extreme climatic disasters, drought is the most complicated, recurring, and least understood natural disaster (Islam et al. 2017; Zhang et al. 2019; Uddin et al. 2020). Drought affects millions of people and causes tremendous environmental degradation, social crisis, livelihood problems, economic disruption, and loss of lives (Habiba and Shaw 2012; Islam and Khan 2018; Pei et al. 2018; Tasnuva et al. 2020; Salam et al. 2021). Drought is a major threat to reduce and loss crop production in Bangladesh (Ahmed et al. 2019), which has been influenced by regional climate change in recent times (Habiba et al. 2014; Islam et al. 2014; Mardy et al. 2018; Zinat et al. 2020). Furthermore, the northern region covering the Teesta River Basin is one of the largest crops producing regions of Bangladesh, of which more than $40 \%$ of the area are rain-fed agriculture, and this Basin has experienced different levels (e.g., moderate, severe) of drought risk (Mainuddin et al. 2015). To cope with the detrimental impacts of drought on agricultural crop production and ensure food security, it is important to increase the understanding of people's drought risk perception as well as ensure a drought-resistant agricultural system.

The risk appraisal is an integral component of disaster risk reduction and sustainability perspectives (Zhou et al. 2015; Rana and Routray 2016). Members of the same community perceived different opinions toward several natural hazards, which influence them to take a different decision on a critical issue, resource allocation, and making policy (Alderman et al. 1995). These households decisions are crucial for alleviating any hazard and disaster risk as this is directly related to resource distribution either intellectual or physical resource. Implementation and formulation of drought risk reduction strategies have recently been attracted more attention among policymakers and practitioners in this basin area because of the extensive effects of climate change, increasing the intensity and frequency of drought hazards, and loss of agricultural crop production.

Understanding peoples' drought risk perception can assist to devise effective drought risk reduction policies and strategies under changing climate conditions, particularly in water deficit areas in the lower Teesta River Basin in Bangladesh. Previous studies in Bangladesh have been concentrated on the drought effects on agriculture (Habiba et al. 2012; Islam et al. 2014; 2021), food production (Ericksen et al. 1993), economy, and society (Ferdous and Mallick 2019). Besides, Habiba et al. (2012) assessed people's perception and adaptation plans to cope with drought in the Northwest Bangladesh. Few studies exist in some other areas in Bangladesh about drought impacts and adaptations (Mardy et al. 2018; Habiba et al. 2011, 2013; Shahid 2010).

Actual vs perceived risk assessment is an interesting research area among scholars in recent decades. Sattar and Cheung (2019) assessed the actual vs perceived cyclone risk in three communities of southern coastal Bangladesh and found that female households perceive greater risk than male participants in terms of risk perception and proposed some cyclone risk reduction measures. Rana and Routray (2016) reported actual versus perceived 
flood risk and found noteworthy spatial variations in three urban cities in Pakistan. Previous studies have explored the coping strategies for drought risk reduction purposes only by examining people's perceptions in Bangladesh (Shahid and Behrawan, 2008; Mardy et al. 2018; Al-Amin et al. 2019; Roy et al. 2020). Up to now, no prior research has explored the actual $v s$ perceived drought risk based on both household's and expert's views in the lower Teesta River Basin of Bangladesh. This study intends to fill this research gap. Consequently, this study aims to appraise actual vs perceived drought risk at the household and expert level in the lower Teesta River Basin in Bangladesh. The planners and stakeholders will be able to know which gender and socioeconomic group need more policy priority to enlighten and educate for facing the increasing disasters and hazards. Disaster preparedness and mitigation strategies will reduce drought risks and losses and thus make a drought-resilient society.

\section{Materials and methods}

\subsection{Selection of the study area}

Teesta River Basin is the home of around 30 million people. The northern part of Bangladesh occupies about 71\%, Sikkim 2\%, and West Bengal 27\% of the Teesta Basin (Syed et al. 2017). Approximately 3 million people are directly and indirectly affected by drought with tremendous damage to infrastructure, livestock, and agricultural crop production in the northern Bangladesh (Islam et al. 2014). This Basin often faces temperatures up to 45 ${ }^{\circ} \mathrm{C}$ more in the pre-monsoon season, and the temperature falls at $5{ }^{\circ} \mathrm{C}$ in some areas in the winter (Islam et al. 2019). This Basin faces frequent climatic extremes that differ from the rest of the country's climatic conditions (Banglapedia 2014).

This study selected the Kaunia, Kishoreganj, and Hatibandha Upazilas, respectively, from Rangpur, Nilphamari, and Lalmonirhat districts based on the severity on drought (Fig. 1). According to Bangladesh Bureau of Statistics (BBS 2014), mouza is the lowest administrative unit in Bangladesh that contains one or more villages. For this study, mouza is considered for collecting more precise data. Data were collected from Ganai, Ismail, and Par Sekh Sundar mouza of Tepamadhupur, Kishoreganj, and Saniajan unions, respectively.

From a climatological perspective, this area is distinct from other regions of the country, especially rainfall and temperature. Rainfall is unevenly distributed in this Basin from the ranges of 1120 to $1323 \mathrm{~mm}$ at an annual scale (Islam et al. 2017).

\subsection{Sample size, questionnaire design, and data collection}

Data collection from several extensive field visits was performed to know the basic information of the designated study areas for the subsequent design of the study. The total population of Ganai, Ismail, and Par Sekh Sundar were 1055, 1174, and 484, respectively (BBS 2014, 2015). The formula proposed by Cochran (1977) was used to calculate the sample size of each mouza. According to Cochran's formula, the calculated sample size $(p<0.05$ and error value at $< \pm 7 \%)$ was 165,168 , and 137 for Ganai, Ismail, and Par Sekh Sundar mouza, respectively. The present study took the round number of 160, 160, and 130 as the sample size for Ganai, Ismail, and Par Sekh Sundar mouza, respectively. In total, 450 sample sizes were considered for collecting information from households. To complement data from the individual household level, 450 


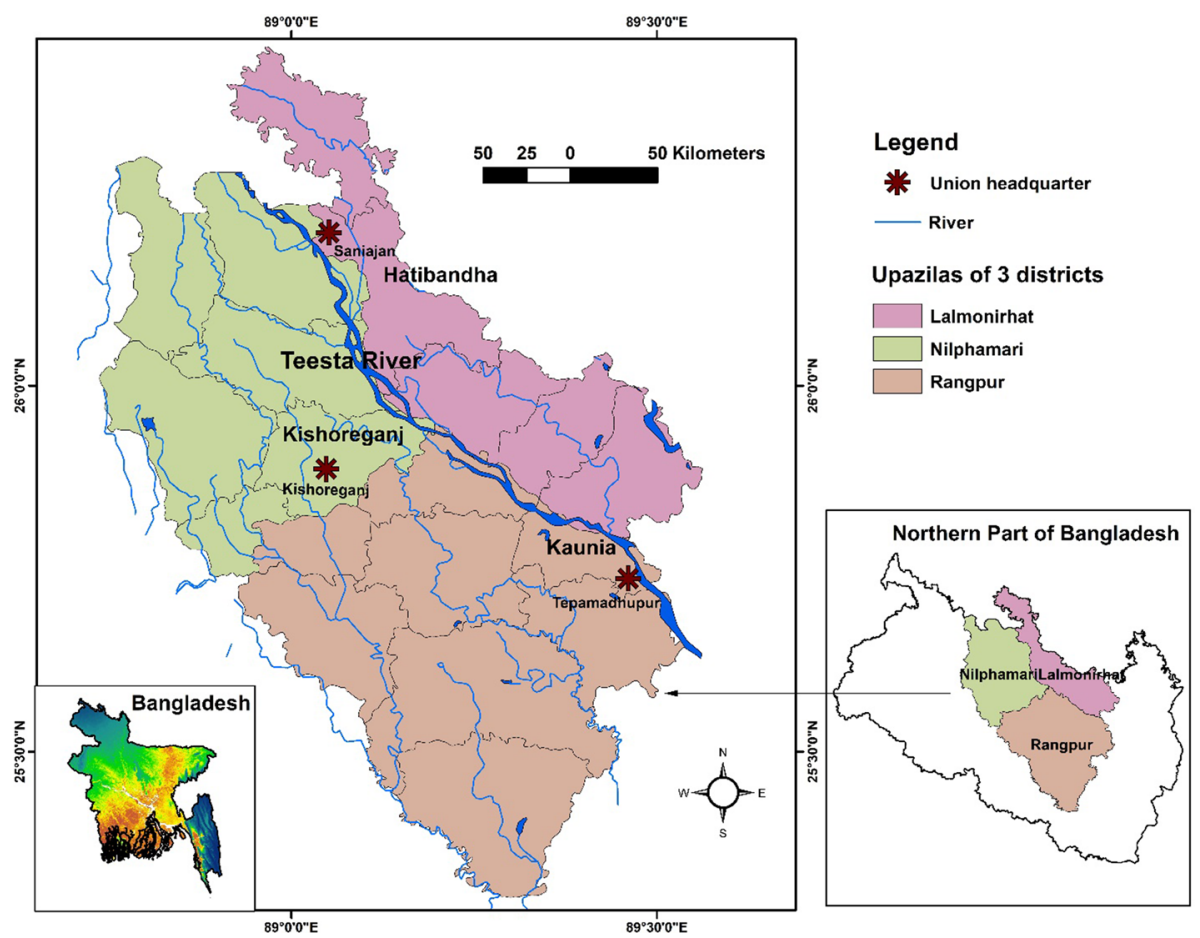

Fig. 1 Location map showing the lower Teesta River Basin of northern Bangladesh

respondents were interviewed about their overall perceptions of drought risk. Opinions of 45 experts ( 20 females and 25 males) from the government officials, non-government officials, researchers, university teachers, and practitioners from Bangladesh who are actively involved in the disaster management field were considered for collecting data for perceived drought risk assessment at expert level.

Before finalizing the structured questionnaire, pre-testing of survey questionnaire was conducted in July 2019 for checking the validity and relevancy of the questions. The final questionnaire was developed based on the feedbacks found from the respondents by a pre-testing survey. The questionnaire was divided into two main parts. One was for collecting data for assessing actual risk, and the other one was for collecting data for perceived risk assessment. The second section (perceived risk assessment) of the questionnaire was used for collecting information from both households and experts. On the contrary, the first section was used for collecting data from only households. Thus, the questionnaire was divided into six parts in total as: i) socioeconomic status; ii) hazard component of disaster risk; iii) exposure (vulnerability) component of disaster risk; iv) sensitivity (vulnerability) component of disaster risk; v) capacity component of disaster risk; and vi) perceived risk assessment. The II, III, IV, and V sections were under the part of the actual risk assessment. The VI section was used for collecting the opinions from both the households and experts.

Household heads both males and females were considered for data collection. The list of respondent was collected from the Department of Agricultural Extension (DAE). Respondents were selected randomly, and they were first informed about the purpose 
of the study. If someone denied providing any information, then the interviewers proceeded to the next household. Face-to-face interviews of the respondent were conducted in August-September 2019. All the answers needed for the detailed questionnaire were close-ended. The answers were then coded and interpreted employing Statistical Package for the Social Science (SPSS) software (version 23). The indicators and their weights are defined in the next subsection.

\subsection{Indicators and weights}

Based on the extensive review of the previous literature (Supplementary Table S1 and Table S2), 32 and 6 indicators were selected for assessing actual and perceived risks for this study. Descriptions of each indicator along with the related weight values are presented in supplementary material of Table S1 and Table S2. Here, 0 to 1 score based on various indicator classes of actual and perceived risk components was allocated. For instance, the lowest hazard, sensitivity, exposure, and capacity classes are allocated the lowest weight values of less than 1 and higher is 1 . Generally, 1 and 0 weights are utilized for yes and no classes. Three classes are assigned as $0.33,0.67$, and 1; four classes are assigned as 0.2 , $0.4,0.6,0.8$ or $0,0.33,0.67$, and 1 ; and five classes are assigned as $0,0.2,0.4,0.6,0.8$ and 1 or $0,0.25,0.50,0.75$, and 1 . Therefore, the values of both the actual and perceived risk indices are between 1 and 0 . The weights were assigned based on previous studies carried out in different parts of the world, where scholars utilized the same weights for the same indicators as used in the present study (Flanagan et al. 2011; Udmale et al. 2014; Barua et al. 2016; Roy et al. 2015; Nhuan et al. 2016; Karim and Thiel 2017; Saunders and Senkbeil 2017; Zhang et al. 2017; Sattar et al. 2018; Sattar and Cheung 2019). The justification of the selection of indicators is given in supplementary material of Table S1 and Table S2.

\subsection{Actual and perceived risk index}

Risk perception is a component of vulnerability and capacity evaluation (Jamshed et al. 2019). The scientific community has widely accepted the risk Eq. (1) that is a product of hazard and vulnerability divided by capacity or manageability (Zhang et al. 2017; Zhang 2004; Bollin et al. 2003).

$$
\text { Risk }=\frac{\text { Hazard } \times \text { Vulnerability }}{\text { Capacity or manageability }}
$$

where Risk = probability of damage and loss due to disasters and hazards, Hazard = potential occurrence of a natural or man-made event, and physical effect of the disturbance, Vulnerability $=$ lack of capacity of a community to face and adapt to a hazard, and Capacity = community assets and available resources that lessening community susceptibility.

In the present study, Eq. (2) has been adopted for computing the actual drought risk at the household level in the Teesta River Basin, northern Bangladesh (Sattar and Cheung 2019; Bollin et al. 2003).

$$
\text { Drought risk }(\mathrm{R})=\frac{\operatorname{Hazard}(\mathrm{H}) \times \operatorname{Exposure}(\mathrm{E}) \times \operatorname{Sensitivity~}(\mathrm{S})}{\text { Adaptive capacity }(\mathrm{C})} .
$$

Thirty-two indicators/questions were constructed $(6,6,10$, and 10 for hazard $(\mathrm{H})$, exposure (E), sensitivity (S), and capacity (C) component of risk, respectively) for assessing 
actual drought risk at the household level. This was based on the respondents' previous experience of severe drought. Perceived risk was also assessed from both the households and expert perspectives. For assessing perceived risk, six indicators/questions were asked. This was also based on the respondents' previous experience of severe drought. For computing the H, E, S, C, and PR indices, Eq. (3) was considered followed by Rana and Routray (2016), Gain et al. (2015), and Bashierr and Jayant (2014).

$$
C l=\frac{W_{1}+W_{2}+W_{3}+\cdots W_{n}}{n}=\sum_{i=1}^{n} \frac{W i}{n}
$$

where CI $1 / 4=$ composite index, W1 to $\mathrm{Wn} 1 / 4=$ respective weights employed to indicators, and $n 1 / 4=$ number of the indicators used for computing the CI.

Following the composite index, Hazard Index (HI), Exposure Index (EI), Sensitivity Index (SI), Capacity Index (CAI), and Perceived Risk Index (PRI) are computed, which are defined in Eqs. (4-9)

$$
\begin{gathered}
\text { Hazard Index }(\mathrm{HI})=\frac{\sum_{i=1}^{6} H W_{i}}{n} \\
\text { Exposure Index }(\mathrm{EI})=\frac{\sum_{i=1}^{6} E W_{i}}{n} \\
\text { Sensitivity Index }(\mathrm{SI})=\frac{\sum_{i=1}^{10} S W_{i}}{n} \\
\text { Capacity Index }(\mathrm{CI})=\frac{\sum_{i=1}^{10} C W_{i}}{n} \\
\text { Percieved Risk Index }(\mathrm{PRI})=\frac{\sum_{i=1}^{6} P W_{i}}{n} \\
\text { Actual Risk }=\frac{\mathrm{HI} *(\mathrm{EI} * \mathrm{SI})}{\mathrm{CAI}} .
\end{gathered}
$$

\subsection{Data homogeneity}

Risk indices were analyzed using one-way analysis of variance (one-way ANOVA) using SPSS software. To observe data homogeneity, a one-sample t-test was performed and the results reveal that the actual risk and perceived risk (both households and experts) values are 99\% ( $p$-value 0.000) significant (Supplementary Table S3). One-sample Kolmogorov-Smirnov test also indicates that all risk values are $99 \%(p<0.01)$ significant. The Chi-square test gives the same result as all risk values are 99\% significant (Supplementary Table S3). All the above test results indicate that the estimated risk values are valid for further analyses. 


\subsection{Ethics}

Participants were informed of the specific aim of this work before proceeding to the survey. Participant's consent was taken before the questionnaire survey, and their anonymity was confirmed. The survey was done only once, and the survey could be completed/terminated whenever they wished. The questionnaire survey content and procedure were properly reviewed and approved by the proposal evaluation and ethical committee of the Department of Disaster Management of Begum Rokeya University, Rangpur.

\section{Results}

\subsection{Actual risk assessment at the household level}

Table 1 represents the socioeconomic status of the participants. Most houses (made of bamboo and mud) are kutcha. The light of education has not enlightened the area well. Most of the respondents who involve in farming practices are male. Maximum farmers are illiterate here. Some are involved in other secondary jobs such as business, day laborer, and so forth.

Table 1 Socioeconomic status of the respondents

\begin{tabular}{|c|c|c|c|c|}
\hline Socioeconomic characteristics & Description & $\begin{array}{l}\text { Ganai (fre- } \\
\text { quency) }\end{array}$ & $\begin{array}{l}\text { Par Sekh Sundar } \\
\text { (frequency) }\end{array}$ & $\begin{array}{l}\text { Ismail } \\
\text { (fre- } \\
\text { quency) }\end{array}$ \\
\hline \multirow[t]{4}{*}{ Age } & $<30$ & 30 & 43 & 31 \\
\hline & $31-45$ & 64 & 46 & 53 \\
\hline & $46-60$ & 47 & 30 & 56 \\
\hline & $>60$ & 13 & 11 & 20 \\
\hline \multirow[t]{2}{*}{ Sex } & Male & 110 & 102 & 117 \\
\hline & Female & 50 & 28 & 43 \\
\hline \multirow[t]{5}{*}{ Educational status } & Illiterate & 37 & 42 & 59 \\
\hline & Primary & 76 & 50 & 58 \\
\hline & Secondary & 32 & 25 & 32 \\
\hline & Higher secondary & 11 & 7 & 9 \\
\hline & Graduate & 4 & 6 & 2 \\
\hline \multirow[t]{5}{*}{ Occupation } & Unemployed & 10 & 14 & 12 \\
\hline & Agriculture & 64 & 60 & 44 \\
\hline & Business & 10 & 17 & 43 \\
\hline & Day labor & 64 & 25 & 28 \\
\hline & Govt./other services & 12 & 14 & 33 \\
\hline \multirow[t]{5}{*}{ Income } & $<5000$ & 59 & 50 & 56 \\
\hline & $5000-10,000$ & 84 & 53 & 51 \\
\hline & $10,000-15,000$ & 11 & 14 & 21 \\
\hline & $15,000-20,000$ & 5 & 10 & 19 \\
\hline & $>20,000$ & 2 & 3 & 13 \\
\hline
\end{tabular}


Among the three sites, Ganai shows the highest risk value of 0.35, whereas Par Sekh Sundar (0.27) and Ismail (0.29) show the lowest risk. The people of Ganai pose a higher vulnerability to drought hazards. ANOVA test also reveals that there exists no significant difference between the area of Par Sekh Sundar and Ismail, but there exists a significant difference between Ganai and the other two areas (Par Sekh Sundar and Ismail). It is widely reported that the risk of a hazard extremely varies from individual to individual, and the results of the present study also comply with this general fact (Fig. 2b). An enormous variety of risks is evident among the participants ranging from 0.1 to 0.8 in this study. Furthermore, the highest risk ( 0.33$)$ value is reported by female respondents and the lowest risk (0.30) value is reported by male respondents, which are statistically significant $(p<0.05)$ (Fig. 3).

Figure 4 shows that the actual risk varies with the variation of respondent educational status, occupation, and income level. Figure 4a shows that illiterate and lower educated (primary passed) people have experienced comparatively high drought risk (0.3) than as secondary $(0.25)$ and higher secondary $(0.24)$ completed people. The graduate people have experienced moderate drought risk (0.27). Although graduate people hold more knowledge about the impacts of drought and better know how to reduce the risk, they face a higher risk than higher secondary and secondary completed people. This is the result of their
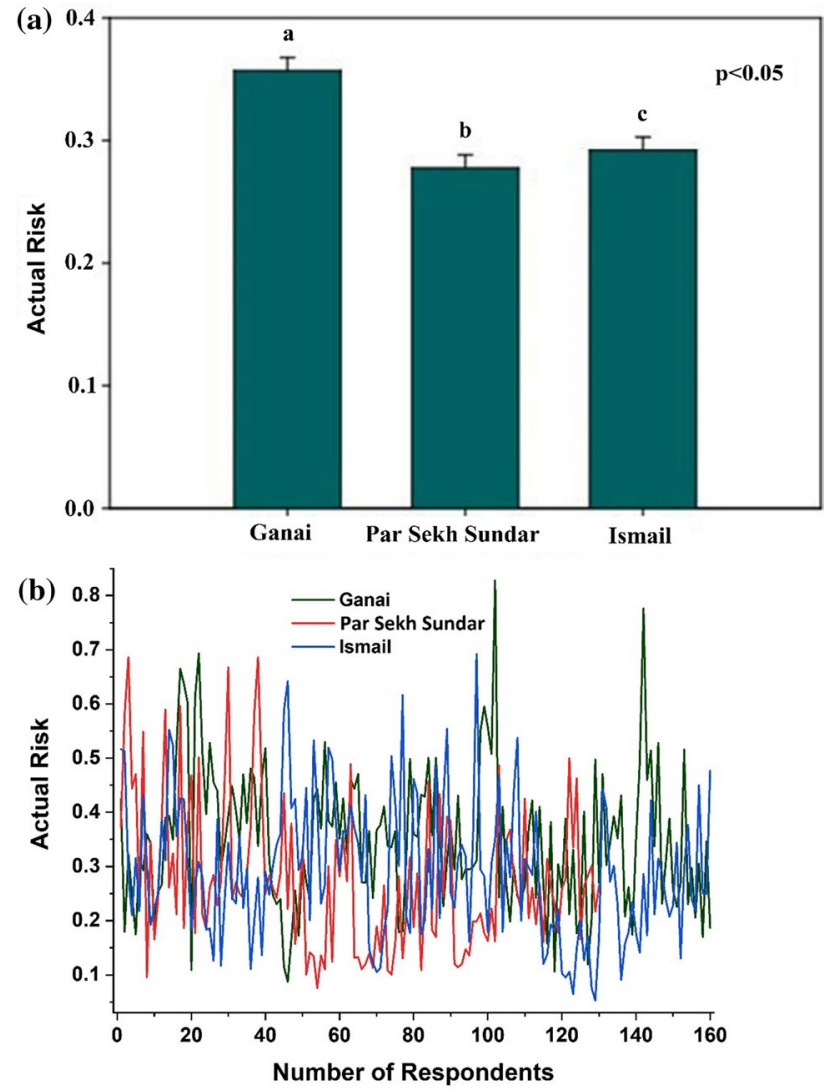

Fig. 2 Index of actual risk: a mean value and $\mathbf{b}$ individual value for the three study areas 


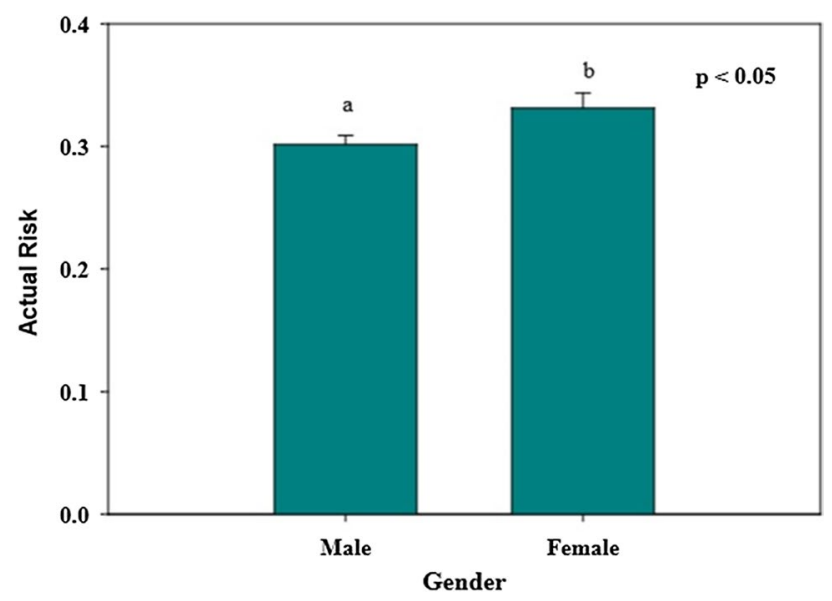

Fig. 3 Actual risk variability based on gender

negligence toward taking appropriate drought risk reduction strategies. Figure $4 \mathrm{~b}$ shows that day labor experienced a comparatively higher risk (0.35) than others as their work is uncertain and is not permanent. Unemployed (0.32) and agricultural workers (0.30) experienced moderate risk. Businessmen (0.26) and Govt. employees and other services (0.27) holders experienced the lowest risk because their income sources are permanent. Figure 4c shows that whose income $<5000$ taka $(0.31)$ and 5000-10,000 taka $(0.32)$ were experiencing high risk and moderate risk $(0.26-0.29)$ was experienced by the income groups of 10,000-15,000 and 15,000-20,000. Low risk (0.22) was experienced by the income group of $>20,000$ taka. This result indicates that higher-income groups have a high drought risk reduction capacity, except for the unemployed group.

\subsection{Perceived risk assessment from households and experts views}

The perceived risk (both households and experts) indices for three areas of Ganai, Par Sekh Sundar, and Ismail were assessed. Figure 5a shows that the people of Ismail perceived high risk (0.69), Ganai moderate risk (0.59), and Par Sekh Sundar low risk (0.55). ANOVA test reveals that there exists a significant difference between the three areas.

Similar to actual risk, perceived risk also differs significantly among individuals ranging from 0.42 to 0.84 (Fig. 5b). There is no notable difference between experts and household views on perceived drought risk (Fig. 6). A slight difference is found in three hazard characters which are likelihood of drought occurrence ( 0.7 for households and 0.65 for experts), ability to cope ( 0.65 and 0.7 for households and experts, respectively), and knowledge about mitigation actions ( 0.84 and 0.7 for households and experts, respectively). The degree of perceived drought risk for the hazard characters of dread (fear), likelihood of future damage from drought, and altering relationships was similar between households and experts (Fig. 6). Approximately similar views are found from both households and experts.

Notable risk difference is found from gender perspectives (Fig. 7). Females perceived higher risk ( 0.63 for households and 0.66 for experts) than males ( 0.60 for households and 0.57 for experts). Perceived risk (households) also varies with the variation of respondent educational status, occupation, and income level (Fig. 8). 

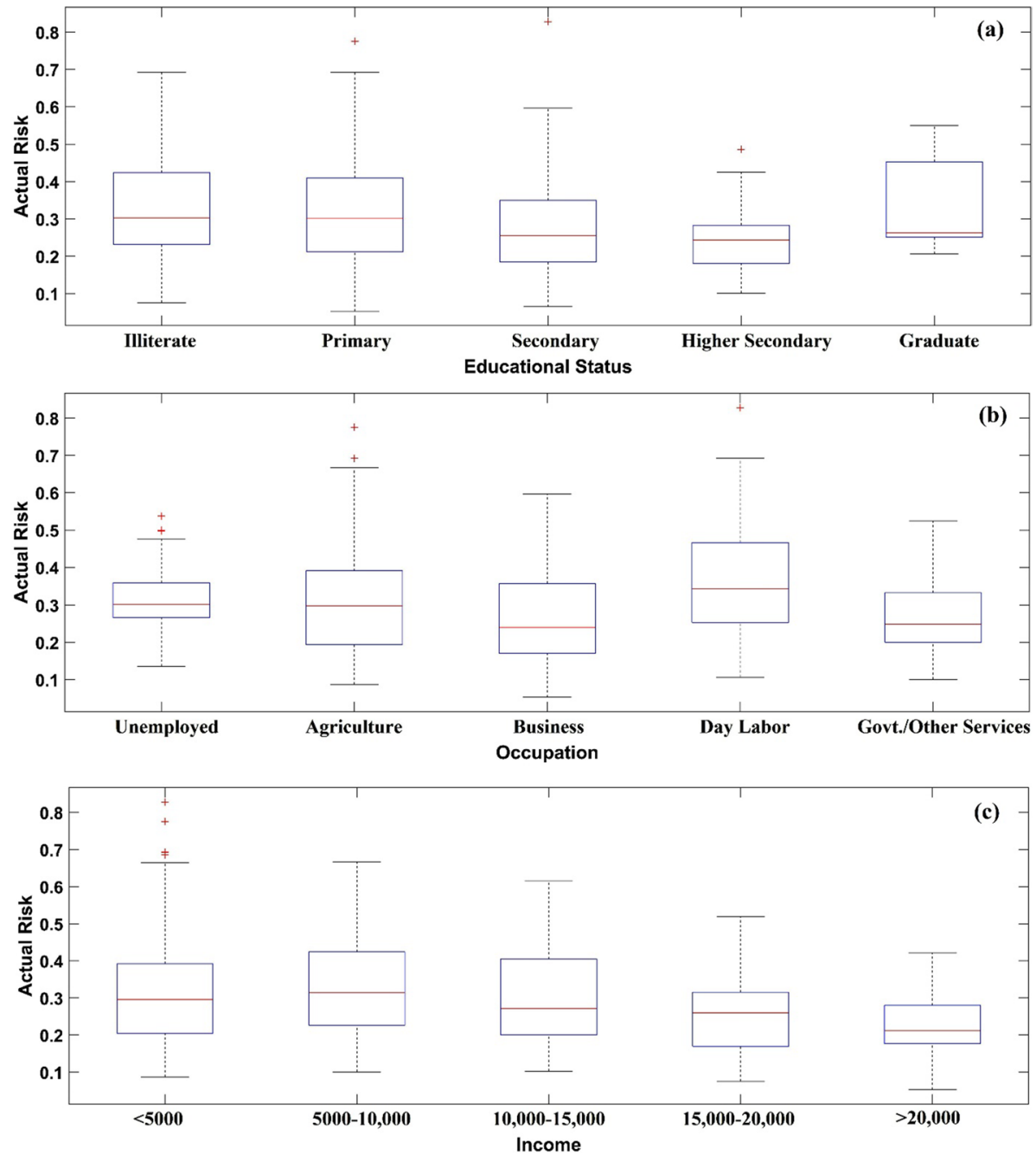

Fig. 4 Dependence of actual drought risk on education, occupation, and income (income is depicted in Bangladeshi Taka, 1 USD = approx. 85 Taka as of May 2, 2021)

Figure 8 a shows that illiterate people perceived higher risk (0.64), moderate risk (0.6) is perceived by primary and secondary school passing people, and lower risk (0.57) is perceived by higher secondary passed as well as graduate people. Figure $8 \mathrm{~b}$ shows that business holders perceived higher risk (0.649) and lower risk (0.6) is perceived by other occupation groups and unemployed people. Figure 8c shows that the people who earn $>20,000$ taka perceived higher risk (0.69) and moderate risk $(0.60-0.64)$ is perceived by other income groups. 

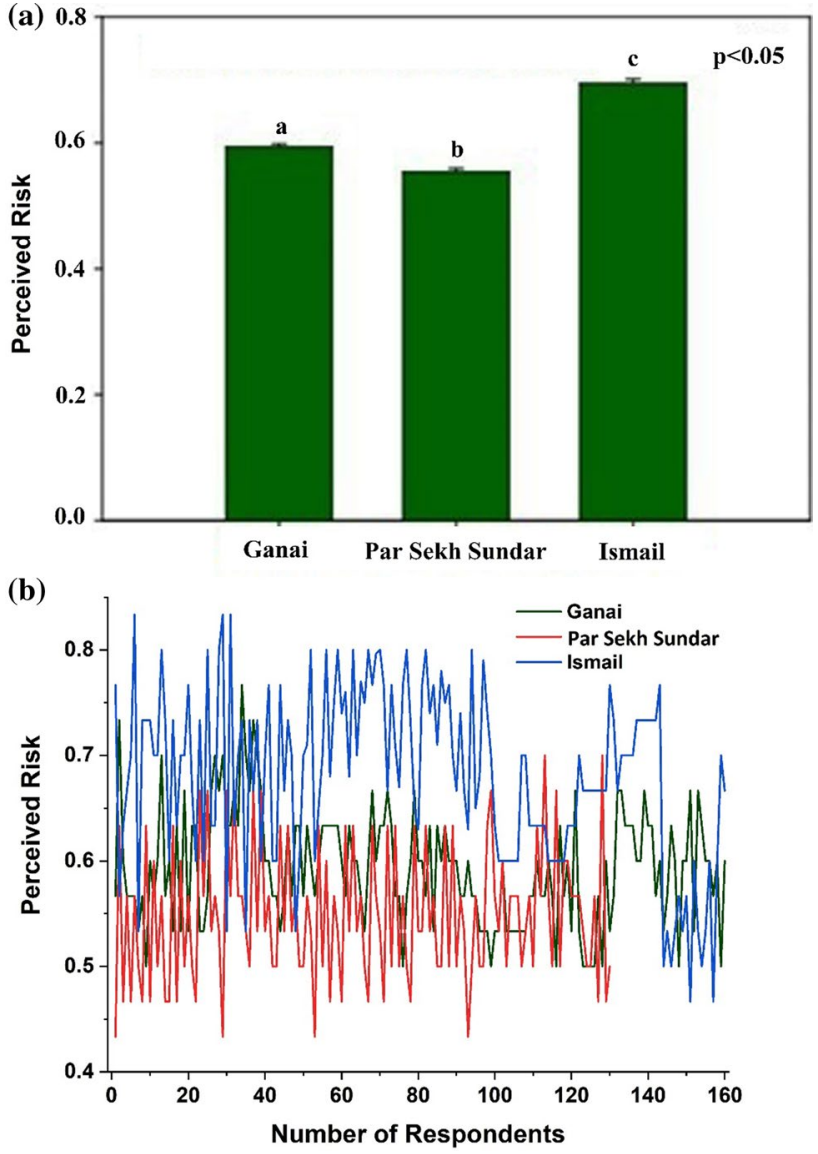

Fig. 5 Index of perceived risk: a mean value and $\mathbf{b}$ individual value at household level for the three study areas

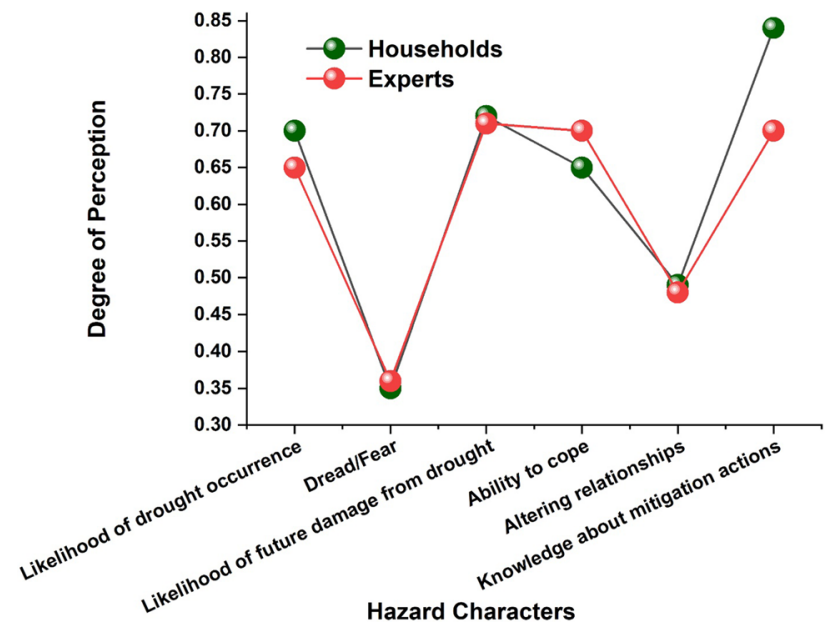

Fig. 6 Degree of perceived risk at household's vs experts 

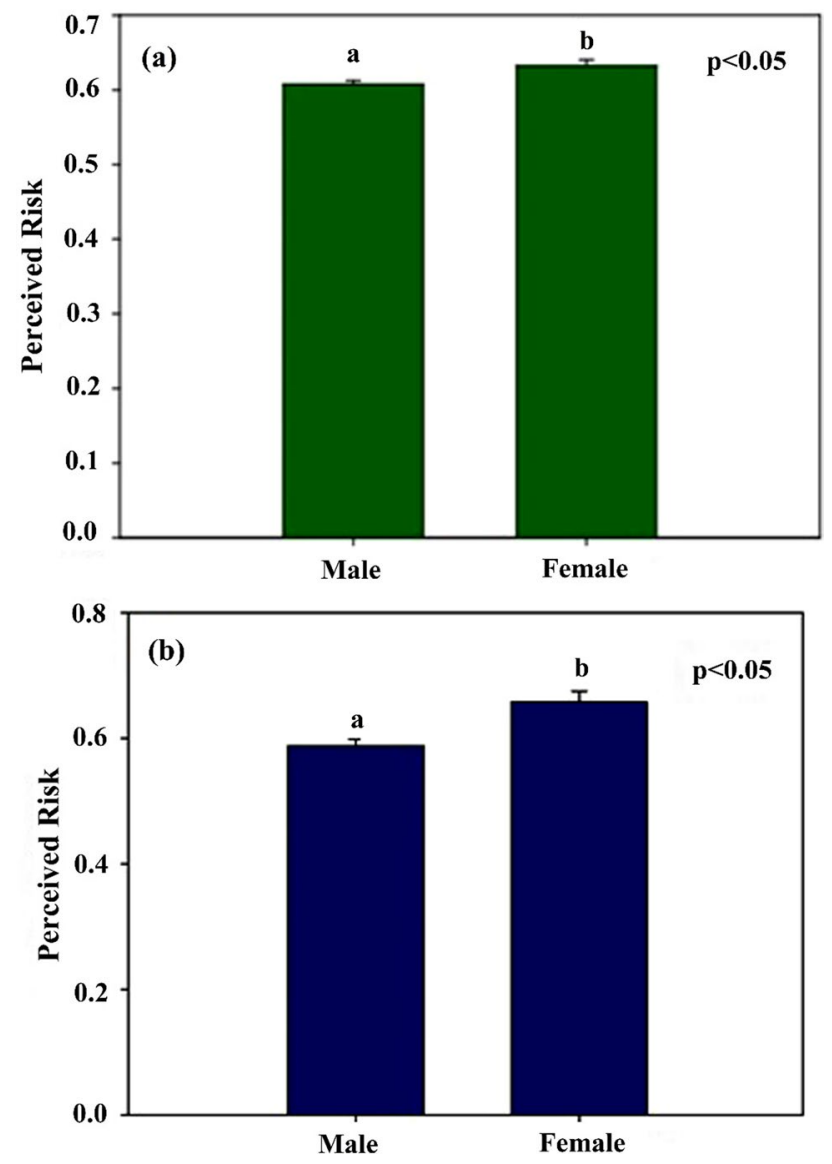

Fig. 7 Risk perceptions from gender perspectives for both $\mathbf{a}$ households and $\mathbf{b}$ experts

\subsection{Correlation between actual risk and perceived risk at the household level}

There is a positive correlation between the actual risk and perceived risk (Fig. 9). The values of correlation are ranged from -1 to +1 . A positive value indicates a proportional relation between variables, and a negative value indicates an inverse relationship between variables. Figure 9 indicates that there exists a positive correlation between actual risk and perceived risk $(p<0.05)$. Pearson's correlation indicates a significant positive correlation between actual risk and perceived risk $(\mathrm{r}=0.322, p<0.05)$. All these results and the figure testify that actual risk has increased with the increase in perceived risk and vice versa.

\section{Discussion}

It was found that actual and perceived risks vary with the variation of gender, educational status, geographic location, occupation, and monthly income which is consistent with the findings of Kellens et al. (2011), Wachinger et al. (2013), Mills et al. (2016), Rana and 

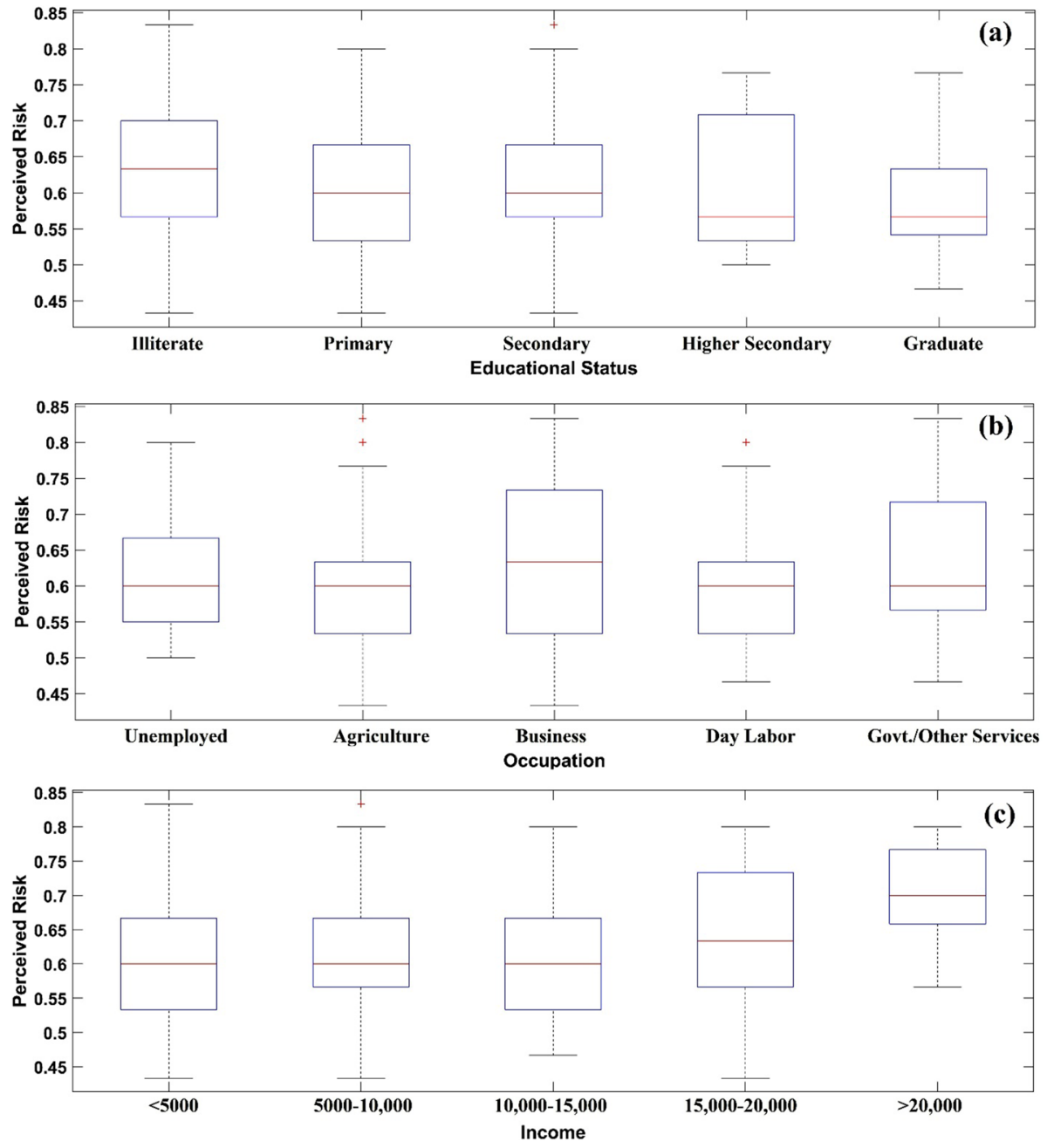

Fig. 8 Dependence of perceived drought risk (households) on education, occupation, and income (income is depicted in Bangladeshi Taka, 1 USD = approx. 85 Taka as of May 2, 2021)

Routry (2016), Sarker (2017), and Sattar and Cheung (2019). No identical difference is found between the opinions of experts and households regarding perceived drought risk except gender. People of Ganai experienced high actual drought risk. On the contrary, people of Ismail and Par Sekh Sundar experienced lower actual drought risk. Unlike actual risk, the people of Ismail, Ganai, and Par Sekh Sundar perceived high, moderate, and low risk, respectively. Buurman et al. (2020) reported based on a household survey that upstream communities experienced high drought risk than downstream communities in central Vietnam. For both actual and perceived (both household's and expert's) drought risk, high risk is reported by female participants. The female perceived more risk ( 0.63 for households and 0.66 for experts) than the male ( 0.60 for households and 0.57 for experts). Sattar and Cheung (2019) also found a similar outcome that females perceived and experienced high risk than males. According to the previous research, women experienced 

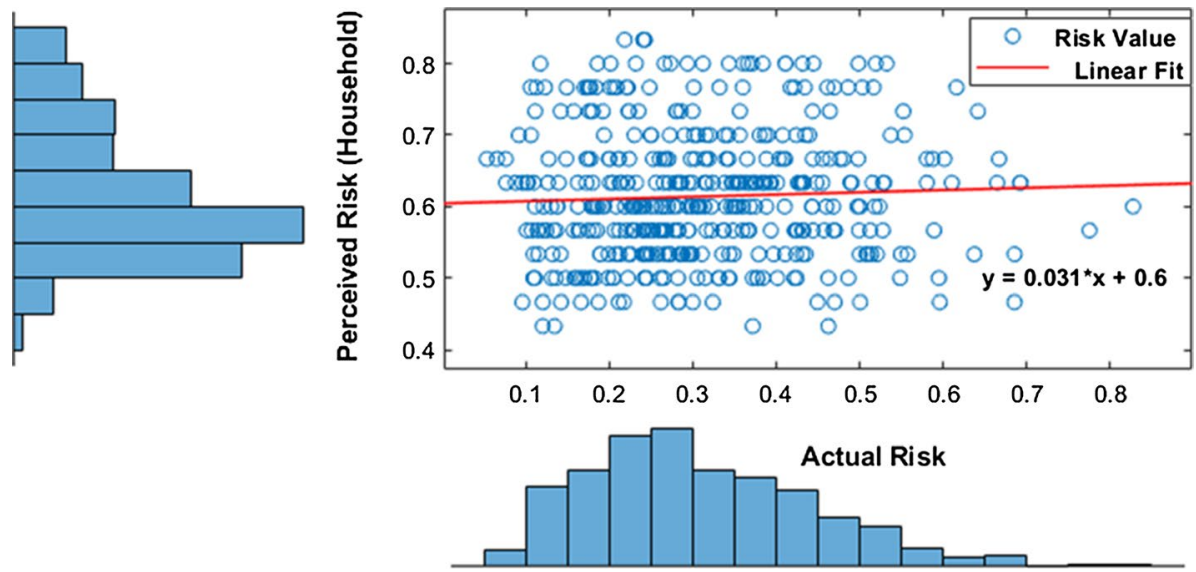

Fig. 9 Correlation between actual and perceived risk at the household level

comparatively high disaster risk than men due to their poor socioeconomic conditions, traditional practices, etc. (UN 2015; Neumayer and Plümper 2007). Khan et al. (2020) explored that girls perceived higher disaster risk than boys that is highly analogous to this present study.

Illiterate and lower educated (primary) people experienced higher risk and graduate people experienced moderate risk. The rest of the groups were reported low risk. Like the actual drought risk, illiterate and lower educated (primary) people perceived higher risk, and comparatively high educated (graduate and higher secondary) people perceived low risk. Roco et al. (2015) stated that comparatively educated people perceived a clear idea of disaster risks that made them understand how to deal with those disasters to reduce the risks. Ullah et al. (2015) and Lucas and Pabuayon (2011) reported that education expands people's knowledge on disasters and climate risk which influences people to take proper initiatives to lower the disasters risks. The income group that has no permanent income source (e.g., day labor) has faced higher risk. In converse, the income group that has a secure source of income (e.g., Govt. employees and other services holders) has faced the lower drought risk. Businessmen perceived higher risk than other income-generating groups. Sam et al. (2019) explored that unemployed people experienced high drought risk which is analogous to the present study. The relation between participant's monthly income (BDT) and drought risk showed a converse relationship. With the increase in income, drought risk decreases and vice versa. De Silva and Kawasaki (2018) explored the same findings as this study that lower-income generating people experienced high drought risk than comparatively high-income generating people. The relation between participant's monthly income (BDT) and perceived drought risk showed a proportional relationship. This perception leads to positive change in the way that people who perceived high risk and also have sufficient financial support taking timely strategies to reduce the upcoming drought risks. Furthermore, this study finds a difference in risk perception between expert and layperson and this finding is consistent with other studies (Peacock et al. 2005; Garvin 2001; Li 2009). An enormous variation in risk perception is found among the households; it is, therefore, urgent to promote awareness-raising programs for drought risk and adaptation so that farmers and community people are well prepared and fully equipped to face future drought events. 
It is a general belief that a person perceives higher risk, who has already been experienced with the higher impacts by any kind of disaster. Similar to Rana and Routray (2016), this study found a slightly positive correlation between actual and perceived risk, whereas Sattar and Cheung (2019) reported reverse or no correlation. It implies that risk perception is a very complex issue that is controlled not only by experience with the hazard but also by some other demographic and socioeconomic factors.

After assessing the actual and perceived risk of the study area, the present study has analyzed the nature and degree of risk and has recommended some of the drought risk reduction strategies appropriate for reducing the risk. The suggested strategies which should be adopted by the community people include afforestation and reforestation, use of drought-tolerant crop varieties and surface water instead of groundwater for agricultural purposes, homestead gardening, livelihood diversification, and establishment of small and medium industries to create employment opportunities. It is also important to establish community organizations and awareness-building programs, to make them more resilient.

\section{Conclusion}

This study aims to appraise actual versus perceived risk in the lower Teesta River Basin of northern Bangladesh. Among the three study sites, the people of Ganai experienced a high actual risk that is significantly diverse from the other two sites of Ismail and Par Sekh Sundar. Results from the perceived risk appraisal reveal that the mean level of perceived drought risk is high from both the household and expert perspective, and the average perceived and expert levels risks of females are comparatively higher than the male counterpart. Risk varies with the variation of the respondent's gender, educational status, occupation, and monthly income. Furthermore, the local inhabitants have to lack knowledge regarding drought risk reduction strategies. The outcomes of this study exhibit a strong correspondence with reality, and these outcomes can help policymakers and practitioners to prepare appropriate drought risk reduction strategies. This study implies that drought risk perception appraisal is a prerequisite for applying any drought risk reduction policy or action plan. One of the key limitations is that this study did not consider the intra-household perception and the factor influencing actual and perceptive risks in char land (island) area. Future studies should consider the intra-household perception for risk assessment and cover all the char lands of the lower Teesta River Basin.

Supplementary Information The online version contains supplementary material available at https://doi. org/10.1007/s11069-021-04789-4.

Acknowledgements The authors would like to acknowledge the Department of Disaster Management, Begum Rokeya University, Rangpur, for other sorts of support. The authors thank all participants who have provided valuable information regarding this research. The authors also acknowledge the anonymous reviewers for improving the quality of the manuscript.

Funding Self-funding.

Data availability Data are available upon request on the corresponding author.

\section{Compliance with ethical standards}

Conflict of interest There is no conflict of interest to publish this research. 
Open Access This article is licensed under a Creative Commons Attribution 4.0 International License, which permits use, sharing, adaptation, distribution and reproduction in any medium or format, as long as you give appropriate credit to the original author(s) and the source, provide a link to the Creative Commons licence, and indicate if changes were made. The images or other third party material in this article are included in the article's Creative Commons licence, unless indicated otherwise in a credit line to the material. If material is not included in the article's Creative Commons licence and your intended use is not permitted by statutory regulation or exceeds the permitted use, you will need to obtain permission directly from the copyright holder. To view a copy of this licence, visit http://creativecommons.org/licenses/by/4.0/.

\section{References}

Ahmed B, Kelman I, Kamruzzaman M, Mohiuddin H, Rahman MM, Das A, Shamsudduha M (2019) Indigenous people's responses to drought in northwest Bangladesh. Environ Dev 29:55-66

Ahsan MN, Warner J (2014) The socioeconomic vulnerability index: a pragmatic approach for assessing climate change led risks - a case study in the south-western coastal Bangladesh. Int $\mathrm{j}$ Disast Ri Reduc 8:32-49. https://doi.org/10.1016/j.ijdrr.2013.12.009

Alam E, Collins AE (2010) Cyclone disaster vulnerability and response experiences in coastal Bangladesh. Disasters 34(4):931-954. https://doi.org/10.1111/j.1467-7717.2010.01176.x

Al-Amin AA, Akhter T, Islam AHMS, Jahan H, Hossain MJ, Prodhan MMH, Mainuddin M, Kirby M (2019) An intra-household analysis of farmers' perceptions of and adaptation to climate change impacts: empirical evidence from drought prone zones of Bangladesh. Clim Change 156(4):545-565

Alderman H, Chiappori PA, Haddad L, Hoddinott J, Kanbur R (1995) Unitary versus collective models of the household: is it time to shift the burden of proof? World Bank Res Obs 10(1):1-19

Armaş I, Avram E (2009) Perception of flood risk in Danube Delta. Romania Nat Hazar 50(2):269-287. https://doi.org/10.1007/s11069-008-9337-0

Banglapedia (2014) Drought in Bangladesh. http://en.banglapedia.org/index.php/Drought. Accessed 15 May 2021

Barua U, Akhter MS, Ansary MA (2016) District-wise multi-hazard zoning of Bangladesh. Nat Hazar 82(3):1895-1918. https://doi.org/10.1007/s11069-016-2276-2

Bashier AH, Jayant KR (2014) Vulnerability to flood-induced public health risks in Sudan. Disas Prev Manag 23(4):395-419. https://doi.org/10.1108/DPM-07-2013-0112

BBS (2014) Small Area Atlas Bangladesh, Bangladesh bureau of statistics, statistics and information division, ministry of planning. Government of the People's Republic of Bangladesh, Dhaka

BBS (2015) Small Area Atlas Bangladesh, Bangladesh bureau of statistics, statistics and information division, ministry of planning. Government of the People's Republic of Bangladesh, Dhaka

Birkmann J, Cardona OD, Carreño ML, Barbat AH, Pelling M, Schneiderbauer S, Welle T (2013) Framing vulnerability, risk and societal responses: the MOVE framework. Nat Hazar 67(2):193-211. https:// doi.org/10.1007/s11069-013-0558-5

Bollin C, Cardenas C, Hahn GH, Vatsa KS (2003) Disaster risk management by communities and local governments. Inter-American Development Bank, Washington, D.C. https://publications.iadb.org/en/disas ter-risk-management-communities-and-local-governments. Accessed 15 May 2021

Boruff BJ (2009) Environmental hazards: assessing risk and reducing disasters. Geo Res 47(4):454-455. https://doi.org/10.1111/j.1745-5871.2009.00611.x

Buurman J, Bui DD, Du LTT (2020) Drought risk assessment in Vietnamese communities using household survey information. Int J Water Resour Dev 36(1):88-105

Cochran WG (1977) Sampling techniques, 3rd edn. Wiley, New York

Cutter SL, Boruff BJ, Shirley WL (2003) Social vulnerability to environmental hazards. Soc Sci Quart 84(2):242-261. https://doi.org/10.1111/1540-6237.8402002

Dastagir MR (2015) Modeling recent climate change induced extreme events in Bangladesh: a review. Wea Clim Extremes 7:49-60. https://doi.org/10.1016/j.wace.2014.10.003

De Silva MMGT, Kawasaki A (2018) Socioeconomic vulnerability to disaster risk: a case study of flood and drought impact in a rural Sri Lankan community. Ecol Econ 152:131-140

Dilley M, Boudreau TE (2001) Coming to terms with vulnerability: a critique of the food security definition. F Poli 26(3):229-247. https://doi.org/10.1016/S0306-9192(00)00046-4

Ekpoh IJ (1999) Rainfall and peasant agriculture in northern Nigeria. Glob J Pure Appl Sci 5(1999):123-128

Ericksen NJ, Ahmad QK, Chowdhury AR (1993) Socio-economic implications of climate change for Bangladesh. Bangladesh Unnayan Parishad, Dhaka, p 1 
Fedeski M, Gwilliam J (2007) Urban sustainability in the presence of flood and geological hazards: the development of a GIS-based vulnerability and risk assessment methodology. Lands Ur Plann 83(1):50_ 61. https://doi.org/10.1016/j.landurbplan.2007.05.012

Ferdous J, Mallick D (2019) Norms, practices, and gendered vulnerabilities in the lower Teesta Basin, Bangladesh. Env Dev 31:88-96

Field CB, Barros V, Stocker TF, Dahe Q (2012) Managing the risks of extreme events and disasters to advance climate change adaptation: special report of the intergovernmental panel on climate change. Cambridge University Press

Flanagan BE, Gregory EW, Hallisey EJ, Heitgerd JL, Lewis B (2011) A social vulnerability index for disaster management. J Homeland Sec Emer Manage. https://doi.org/10.2202/1547-7355.1792

Gain AK, Mojtahed V, Biscaro C, Balbi S, Giupponi C (2015) An integrated approach of flood risk assessment in the eastern part of Dhaka City. Nat Hazards 79(3):1499-1530. https://doi.org/10.1007/ s11069-015-1911-7

Garvin T (2001) Analytical paradigms: the epistemological distances between scientists, policy makers, and the public. Ri Analy 21(3):443-456. https://doi.org/10.1111/0272-4332.213124

Habiba U, Shaw R, Hassan A (2013) Drought risk and reduction approaches in Bangladesh. Disaster risk reduction approaches in Bangladesh. Springer, Tokyo, pp 131-164

Habiba U, Shaw R, Takeuchi Y (2011) Drought risk reduction through a Socio-economic, Institutional and Physical approach in the northwestern region of Bangladesh. Env Hazard 10:121-138

Habiba U, Shaw R, Takeuchi Y (2012) Farmer's perception and adaptation practices to cope with drought: perspectives from Northwestern Bangladesh. Int J Disas Ris Reduc 1:72-84. https://doi.org/10.1016/j. ijdrr.2012.05.004

Habiba U, Shaw R, Takeuchi Y (2014) Farmers' adaptive practices for drought risk reduction in the northwest region of Bangladesh. Nat Hazard 72(2):337-359. https://doi.org/10.1007/s11069-013-1011-5

Hahn MB, Riederer AM, Foster SO (2009) The Livelihood Vulnerability Index: a pragmatic approach to assessing risks from climate variability and change-a case study in Mozambique. Glob Env Chan 19(1):74-88. https://doi.org/10.1016/j.gloenvcha.2008.11.002

Islam ARMT, Shen S, Hu Z, Rahman MA (2017) Drought hazard evaluation in boro paddy cultivated areas of western Bangladesh at current and future climate change conditions. Adv Meteorol 3514381:1-12. https://doi.org/10.1155/2017/3514381

Islam ARMT, Shen S, Yang S, Hu Z, Chu R (2019) Assessing recent impacts of climate change on design water requirement of Boro rice season in Bangladesh. Theor Appl Climatol 138(2019):97-113. https:// doi.org/10.1007/s00704-019-02818-8

Islam ARMT, Tasnuva A, Sarker SC, Rahman MM, Mondal MSH, Islam MMU (2014) Drought in Northern Bangladesh: social, agroecological impact and local perception. Int J Ecosyst 4(3):150-158. https://doi.org/10.5923/j.ije.20140403.07

Islam MR, Khan NA (2018) Threats, vulnerability, resilience and displacement among the climate change and natural disaster-affected people in South-East Asia: an overview. J Asia Pac Econ 23(2):297-323

Islam ARMT, Mehra B, Salam R, Siddik NA, Patwary MA (2021) Insight into farmers' agricultural adaptive strategy to climate change in northern Bangladesh. Environ Dev Sustain 23:2439-2464. https:// doi.org/10.1007/s 10668-020-00681-6

Jamshed A, Rana IA, Mirza UM, Birkmann J (2019) Assessing relationship between vulnerability and capacity: an empirical study on rural flooding in Pakistan. Int J Disaster Risk Reduc 36:101109. https://doi.org/10.1016/j.ijdrr.2019.101109

Karim MR, Thiel A (2017) Role of community based local institution for climate change adaptation in the Teesta riverine area of Bangladesh. Clim Risk Manage 17:92-103. https://doi.org/10.1016/j.crm.2017. 06.002

Kellens W, Zaalberg R, Neutens T, Vanneuville W, De Maeyer P (2011) An analysis of the public perception of flood risk on the Belgian coast. Ris Anal 31:1055-1068

Khan S (2012) Vulnerability assessments and their planning implications: a case study of the Hutt Valley. New Zealand Nat Hazar 64(2):1587-1607. https://doi.org/10.1007/s11069-012-0327-x

Khan AA, Rana IA, Nawaz A (2020) Gender-based approach for assessing risk perception in a multi-hazard environment: a study of high schools of Gilgit, Pakistan. Int J of Dis Risk Red 44:101427. https://doi. org/10.1016/j.ijdrr.2019.101427

Krug EG, Kresnow MJ, Peddicord JP, Dahlberg LL, Powell KE, Crosby AE, Annest JL (1998) Suicide after natural disasters. N Engl J Med 338(6):373-378. https://doi.org/10.1056/NEJM199802053380607

Kulatunga U, Wedawatta G, Amaratunga D, Haigh R (2014) Evaluation of vulnerability factors for cyclones: the case of Patuakhali, Bangladesh. Int J Disas Ri Reduc 9:204-211. https://doi.org/10.1016/j.ijdrr. 2014.05.011 
Li GM (2009) Tropical cyclone risk perceptions in Darwin, Australia: a comparison of different residential groups. Nat Hazard 48(3):365-382. https://doi.org/10.1007/s11069-008-9269-8

Lucas MP, Pabuayon IM (2011) Risk perceptions, attitudes, and influential factors of rainfed lowland rice farmers in Ilocos Norte. Philippines. Asian J Agric Dev 8(1362-2016-107714):61-77: https://doi.org/ 10.22004/ag.econ.199327

Mainuddin M, Kirby M, Chowdhury RAR, Shah-Newaz SM (2015) Spatial and temporal variations of and the impact of climate change on, the dry season crop irrigation requirements in Bangladesh. Irrig Sci 33:107-120. https://doi.org/10.1007/s00271-014-0451-3

Mallick B, Ahmed B, Vogt J (2017) Living with the risks of cyclone disasters in the south-western coastal region of Bangladesh. Env 4(1):13. https://doi.org/10.3390/environments4010013

Mardy T, Uddin M, Sarker M, Roy D, Dunn E (2018) Assessing coping strategies in response to drought: a micro level study in the north-west region of Bangladesh. Climate 6(2):23. https://doi.org/10.3390/ cli6020023

Mills M, Mutafoglu K, Adams VM, Archibald C, Bell J, Leon JX (2016) Perceived and projected flood risk and adaptation in coastal Southeast Queensland. Australia Clim Change 136(3-4):523-537

Mortimore MJ, Adams WM (2001) Farmer adaptation, change and 'crisis' in the Sahel. Glob Env Chan 11(1):49-57. https://doi.org/10.1016/S0959-3780(00)00044-3

Neumayer E, Plümper T (2007) The gendered nature of natural disasters: the impact of catastrophic events on the gender gap in life expectancy, 1981-2002. Ann Assoc Am Geogr 97(3):551-566

Nhuan MT, Tue NT, Hue NTH, Quy TD, Lieu TM (2016) An indicator-based approach to quantifying the adaptive capacity of urban households: the case of Da Nang city, Central Vietnam. Urban Clim 15:60-69. https://doi.org/10.1016/j.uclim.2016.01.002

Peacock WG, Brody SD, Highfield W (2005) Hurricane risk perceptions among Florida's single family homeowners. Landsc Urb Plan 73:120-135. https://doi.org/10.1016/j.landurbplan.2004.11.004

Pei W, Fu Q, Liu D, Li TX, Cheng K, Cui S (2018) Spatiotemporal analysis of the agricultural drought risk in Heilongjiang Province, China. Theor Appl Climatol 133(1):151-164

Phung D, Rutherford S, Dwirahmadi F, Chu C, Do CM, Nguyen T, Duong NC (2016) The spatial distribution of vulnerability to the health impacts of flooding in the Mekong Delta. Vietnam Int J Biometeorol 60(6):857-865. https://doi.org/10.1007/s00484-015-1078-7

Qasim S, Khan AN, Shrestha RP, Qasim M (2015) Risk perception of the people in the flood prone Khyber Pukhthunkhwa province of Pakistan. Int J Disas Ri Reduc 14:373-378. https://doi.org/10. 1016/j.ijdrr.2015.09.001

Rana IA, Routray JK (2016) Actual vis-à-vis perceived risk of flood prone urban communities in Pakistan. Int J Disast Risk Reduc 19:366-378. https://doi.org/10.1016/j.ijdrr.2016.08.028

Roco L, Engler A, Bravo-Ureta BE, Jara-Rojas R (2015) Farmers' perception of climate change in mediterranean Chile. Reg Environ Change 15(5):867-879

Roy C, Sarkar SK, Åberg J, Kovordanyi R (2015) The current cyclone early warning system in Bangladesh: providers' and receivers' views. Int J Disas Risk Reduc. https://doi.org/10.1016/j.ijdrr.2015. 02.004

Roy D, Datta A, Kuwornu JK, Zulfiqar F (2020) Comparing farmers' perceptions of climate change with meteorological trends and examining farm adaptation measures in hazard-prone districts of northwest Bangladesh. Environ Dev Sustain. https://doi.org/10.1007/s10668-020-00989-3

Saha CK (2015) Dynamics of disaster-induced risk in southwestern coastal Bangladesh: an analysis on tropical Cyclone Aila. Nat Hazards 75(1):727-754. https://doi.org/10.1007/s11069-014-1343-9

Shahid S, Behrawan H (2008) Drought risk assessment in the western part of Bangladesh. Nat Hazards 46:391-413. https://doi.org/10.1007/s11069-007-9191-5

Shahid S (2010) Rainfall variability and the trends of wet and dry periods in Bangladesh. Int J Climatol 30(15):2299-2313. https://doi.org/10.1002/joc.2053

Salam R, Islam ARMT, Shill BK, Alam GMM, Hasanuzzaman M, Hossain MM, Ibrahim SM, Shouse RC (2021) Nexus between vulnerability and adaptive capacity of drought-prone rural households in northern Bangladesh. Nat Hazards 46:391-413. https://doi.org/10.1007/s11069-020-03900-5

Sam AS, Abbas A, Padmaja SS, Kaechele H, Kumar R, Müller K (2019) Linking food security with household's adaptive capacity and drought risk: implications for sustainable rural development. Soc Indic Res 142(1):363-385

Sarker MAR (2017) Farmersperception on climate change-driven rice production loss in drought-prone and groundwater-depleted areas of Bangladesh: an ordered probit analysis. University of Queensland, School of Economics. http://www.uq.edu.au/economics/abstract/579.pdfhttp://www.uq.edu. au/economics/abstract/579.pdf. Accessed 15 May 2021 
Sattar MA, Van Scheltinga CT, Kroeze C (2018) Farmers' perceptions on impacts of climate variability and adaptations to agriculture: a case study of Panchagarh, Bangladesh. J Patuakhali Sci Technol Univ 2018(1 \& 2):211-226

Sattar MA, Cheung KK (2019) Tropical cyclone risk perception and risk reduction analysis for coastal Bangladesh: household and expert perspectives. Int J Disast Risk Reduc 41:101283. https://doi.org/ 10.1016/j.ijdrr.2019.101283

Saunders ME, Senkbeil JC (2017) Perceptions of hurricane hazards in the mid-Atlantic region. Meteor Applic 24(1):120-134. https://doi.org/10.1002/met.1611

Syed A, Haq A, Uzzaman A, Goodrich CG, Mallick D, Mini G, Sharma G, Nyima K, Mamnun N, Varma N, Singh P (2017) The Teesta Basin: enough water for power and agriculture for all. Himalayan Adaptation, Water and Resilience (HI-AWARE) Working Paper 12. https://lib.icimod.org/record/ 33669. Accessed 15 May 2021

Tasnuva A, Hossain R, Salam R, Islam ARMT et al (2020) Employing social vulnerability index to assess household social vulnerability of natural hazards: an evidence from southwest coastal Bangladesh. Environ Dev Sustain. https://doi.org/10.1007/s10668-020-01054-9

Terpstra T, Gutteling JM (2008) Households' perceived responsibilities in flood risk management in The Netherlands. Int J Water Res Dev 24:555-565

Uddin MJ, Hu J, Islam ARMT, Eibek KU, Zahan MN (2020) A comprehensive statistical assessment of drought indices to monitor drought status in Bangladesh. Arab J Geosci 13:323. https://doi.org/10. 1007/s 12517-020-05302-0

Udmale P, Ichikawa Y, Manandhar S, Ishidaira H, Kiem AS (2014) Farmers' perception of drought impacts, local adaptation and administrative mitigation measures in Maharashtra State, India. Int J of Dis Ri Reduc 10:250-269

Ullah R, Shivakoti GP, Ali G (2015) Factors effecting farmers' risk attitude and risk perceptions: The case of Khyber Pakhtunkhwa, Pakistan. Int J Disaster Risk Reduct 13:151-157

United Nations International Strategy for Disaster Reduction (2015) Women's leadership in risk-resilient development good practices and lessons learned. Thammada Press, Bangkok

Wachinger G, Renn O, Begg C, Kuhlicke C (2013) The risk perception paradox-implications for governance and communication of natural hazards. Risk Anal 33(6):1049-1065

Zhang F, Chen Y, Zhang J, Guo E, Wang R, Li D (2019) Dynamic drought risk assessment for maize based on crop simulation model and multi-source drought indices. J Clean Prod. https://doi.org/10.1016/j. jclepro.2019.06.051

Zhang J (2004) Risk assessment of drought disaster in the maize growing region of Songliao Plain, China. Agric Ecosyst Environ 102(2):133-153

Zhang W, Wang W, Lin J, Zhang Y, Shang X, Wang X, Ma W (2017) Perception, knowledge and behaviors related to typhoon: a cross sectional study among rural residents in Zhejiang, China. Int J Env Rese Pub Heal 14(5):492. https://doi.org/10.3390/ijerph14050492

Zhou Y, Liu Y, Wu W, Li N (2015) Integrated risk assessment of multi-hazards in China. Nat Hazards 78:257-280. https://doi.org/10.1007/s11069-015-1713-y

Zinat MRM, Salam R, Badhan MA, Islam ARMT (2020) Appraising drought hazard during Boro rice growing period in western Bangladesh. Int J Biometeorol. https://doi.org/10.1007/s00484-020-01949-2

Publisher's Note Springer Nature remains neutral with regard to jurisdictional claims in published maps and institutional affiliations. 